\title{
SISTEM INFORMASI NILAI HSV TANAMAN SAYUR SAWI BERBASIS CITRA HANDPHONE
}

\author{
Reski Idrus*1, Farid Wajidi ${ }^{2}$, Noer Ekafitri Sam ${ }^{3}$ \\ 1, Program Studi Sistem Informasi STMIK Hasan Sulur Wonomulyo, Indonesia \\ 2.Program Studi Teknik Informatika Universitas Sulawesi Barat, Indonesia \\ 3, Program Studi Sistem Informasi STMIK Hasan Sulur Wonomulyo, Indonesia \\ e-mail: *11 reskiidrus17@gmail.com, ${ }^{2}$ faridwajidi@unsulbar.ac.id., ${ }^{3}$ noerekafitrisam.nes@ gmail.com
}

\begin{abstract}
Abstrak
Abstrak - Penelitian ini bertujuan untuk mengetahui nilai hsv pada tanaman sayur sawi. Metode pengolah citra dengan segmentasi warna, Tanaman sayur sawi yang diambil dalam penelitian ini setelah tanaman di semaikan dan di tanam ulang di lahan tertentu atau dari pembibit 0 umur sampai 17 hari kemudian di pindahkan tanaman tersebut, satu hari setelah tanaman sayur sawi tersebut di tanam ulang di lahan yang sudah di siapkan sebelumnya. Tanaman sayur sawi berumur 18 hari sampai 22 hari menghasilkan nilai Hue antara 37,224 \% sampai 29,662 \% , sayur sawi yang berumur 22 hari sampai 26 hari menghasilkan nilai Hue antara 29,662 \% sampai 17,459\%, sayur sawi yang berumur 26 hari sampai 30 hari menghasilkan nilai Hue 17,459 \% sampai 15,755 \%, sayur sawi yang berumur 30 hari sampai 34 hari menghasilkan nilai Hue 15,755 \% samapi 7,483\%. Jika sayur sawi nilai HSVnya kurang dari nilai standar maka diprediksi ada gangguan tanamannya atau kurang baik pertumbuhannya, begitu juga kalau tanamannya melebihi nilai HSV standar bisa dipastikan pertumbuhan tanamannya dalam keadaan baik. Alat yang digunakan adalah kamera handphone vivo 1609 dengan alat bantu tongsit setinggi 5 meter.
\end{abstract}

Kata Kunci : HandPhone Vivo 1609, Tanaman sayur sawi, Tongsit, Kertas putih bundar

\begin{abstract}
Abstract - This study aims to determine the value of hsv in mustard greens. Image processing method with color segmentation, mustard vegetable plants taken in this study after the plants are planted and replanted in certain fields or from seedlings of 0 ages to 17 days later are removed the plants, one day after the mustard vegetable plants are replanted. on land that has been prepared beforehand. Mustard greens aged 18 days to 22 days produce shark values between $37.224 \%$ to $29.662 \%$, mustard greens aged 22 days to 26 days produce shark values between $29.662 \%$ to $17.459 \%$, mustard greens aged 26 days to 30 days produce shark values $17.459 \%$ to $15.755 \%$, mustard greens aged 30 days to 34 days produce a shark value of $15.755 \%$ to $7.483 \%$. If the vegetable HSV value is less than the standard value, it is predicted that there will be plant disturbance or poor growth, likewise if the plant exceeds the standard $H S V$ value, it can be ascertained that the plant growth is in good condition. The tool used is the Vivo 1609 mobile phone camera with a 5 meter high tongsit.
\end{abstract}

Keywords : Mobile Vivo 1609, Mustard greens, Tongsit, Round white paper 


\section{PENDAHULUAN}

Tanaman sayur sawi merupakan komoditas yang digemari masyarakat indonesia dan memiliki nilai komersial, selain itu tanaman sayur sawi memiliki jangka waktu panen yang singkat yaitu antara 30 hari sampai 40 hari tanaman ini sudah bisa di panen, namun untuk mengetahui nilai HSV yang terkandung pada tanaman sayur sawi para petani masih mengalami kesulitan. Sayur sawi termasuk sayuran daun dari keluarga cruciferae yang mempunyai ekonomis tinggi. Tanaman sayur sawi berasal dari Tiongkok (cina) dan Asia Timur. Tanaman sayur sawi umumnya mudah berbunga dan berbiji secara alami baik di dataran tinggi maupun di dataran rendah. Stuktur bunga sawi tersusun dalam tangkai bunga (inflorescentia) yang tumbuh memanjang (tinggi) dan bercabang banyak. Indonesia memiliki kecocokan terhadap iklim, cuaca dan tanahnya sehingga dapat dikembangkan di Indonesia. Budidaya tanaman secara vertikultur dan media tanam yang berbeda berpengaruh terhadap pertumbuhan dan produksi tanaman sawi. ${ }^{[1]}$

Sayur sawi adalah produk pertanian yang banyak dimanfaatkan manusia sebagai bahan pangan, sayur sawi merupakan bahan pangan yang cukup terjangkau bagi masyarakat karena masih banyak dijumpai di pasar-pasar tradisional maupun modern. Tanaman berdaun lebar ini biasa diolah menjadi aneka masakan, sawi termasuk ke dalam kelompok tanaman sayuran daun yang mengandung zat-zat gizi lengkap yang memenuhi syarat untuk kebutuhan gizi masyarakat. Kebutuhan sayur sawi di Indonesia mendorong para petani mengusahakan lahan sayur sawi agar menghasilkan tanaman sayur sawi dengan kualitas serta kuantitas yang optimal. Salah satu usaha yang harus diperhatikan dalam penanaman sayur sawi oleh para petani dan pengusaha sayur sawi adalah pengaruh tingkat ketersediaan air yang cukup bagi pertumbuhan tanaman sayur sawi. Sawi merupakan jenis tanaman yang bisa dibilang cukup mudah untuk dibudidayakan. Hal ini dikarenakan sawi bisa hidup di dataran tinggi maupun di dataran rendah dan bisa ditanaman pada kondisi kering. Selain tidak rumit, menanam sawi untuk konsumsi pribadi juga tidak membutuhkan lahan yang luas ${ }^{[2]}$. Hal tersebut harus diperhatikan dan diusahakan karena pertumbuhan tanaman sayur sawi yang baik akan menghasilkan sayur sawi siap panen dengan kualitas yang baik, sementara itu hasil yang maksimal dapat meningkatkan kesejahteraan petani dan pengusaha sayur sawi. Umumnya sayur sawi yang disukai adalah sawi yang memiliki tangkai daun yang panjang, langsing, berwarna hijau segar, daun lebar memanjang, tipis. Selain itu sawi harus memiliki rasa yang segar, renyah, dan memiliki sedikit sekali rasa pahit.

Berdasarkan latar belakang yang diuraikan tersebut, maka dianggap perlu dilakukan penelitian tentang perbandingan nilai HSV yang terkandung pada tanaman sayur sawi sehingga petani dapat mengetahui kualitas tanamannya dengan menggunakan pengolahan hasil citra yang memanfaatkan teknologi HandPhone. Untuk itu penulis memberi solusi terhadap masalah yang dialami dengan mengambil judul penelitian "Sistem Informasi Nilai HSV Tanaman Sayur Sawi Berbasis Citra HandPhone”.

\section{METODE}

Penelitian ini dilaksanakan di Kecamatan Wonomulyo Kabupaten Polewali Mandar Provinsi Sulawesi Barat dengan menggunakan waktu selama 4 Bulan yaitu pada bulan April sampai Juli 2019 
Metode penelitian yang digunakan adalah kualitatif dan kuantitatif, yaitu penelitian kualitatif ini lebih cenderung pada makna dari dalam, penalaran defenisi suatu situasi tertentu dengan menganalisa studi kasus yang akan di teliti dan penelitian kuantitatif di gunakan karena dalam penelitian ini menerapkan serta mengkaji teori yang sudah ada sebelumnya, yang di awali dengan perumusan masalah, studi kepustakaan, analisa citra digital dan nilai HSV. Aplikasi yang digunakan dalam proses pengambilan data HSV untuk setiap bagian pada gambar sayur, tanah, air dan terpal adalah aplikasi Imagecolorpicker.com ini bisa di buka web browser secara on line.

\subsection{Bahan Penelitian}

Bahan yang digunakan dalam penelitian ini adalah tanaman sayur sawi yang berlokasi di Kecamatan Wonomulyo Kabupaten Polewali Mandar Propinsi Sulawesi Barat, Indonesia. Alat-alat yang digunakan pada penelitian ini adalah :

2.1.1 Hand Phone Type 1609

2.1.2 Perangkat komputer

2.1.3 Tongsit

2.1.4 Kertas berwarna putih bundar berdiameter $20 \mathrm{Cm}$

2.1.5 Terpal

\subsection{Perangkat lunak}

Perangkat lunak yang dibutuhkan dalam penelitian ini untuk menentukan nilai HSV adalah aplikasi Delphi 7

\subsection{Perancangan Pengolahan Citra}

Perancangan pengolahan citra merupakan proses pengolahan citra, ini mempunyai ciri data masukan dan keluaran yang berbentuk citra. Citra digital adalah gambaran dari suatu objek yang diamati dengan menggunakan alat camera ${ }^{[3]}$, dalam hal ini menggunakan kamera HandPhone 1609. Citra yang dihasilkan tersebut akan diolah dengan menggunakan komputer untuk menghasilkan informasi bagi peteni sayur sawi.

\subsection{Interpretasi Citra}

Interpretasi citra adalah suatu kegiatan menganalisis hasil foto yang didapat dari suatu alat yang digunakan untuk mengidentifikasi suatu objek tertentu. sebuah citra yang beruku-ran 256 x 256 pixelyang memiliki 65536 buah pixeldirepresentasikan secara numerik dengan matriks yang terdiri dari 256 baris (diindeks dari 0 sampai 255) dan 256 kolom (diindeks dari 0 sampai 255). ${ }^{[4]}$

\subsubsection{Piksel}

Nilai tiap-tiap entri matriks pada bitmap disebut dengan Piksel (Picture Elements). Banyaknya warna yang ditampilkan dapat mempengaruhi nilai rentan piksel. Jika nilai-nilai pikselnya dibatasi dari 0 hingga 255 maka bitmapnya bernilai sebesar 256. Semakin tinggi nilai bitmap,maka akan semakin bagus gambar yang ditampilkan. Kumpulan piksel-piksel yang tersusun dalam larik dua dimensi biasa disebut dengan citra. Piksel harus dinyatakan dalam bilangan bulat.

\subsection{Pembentukan Citra Digital}

Pembentukan Citra Digital, Perbedaan atas foto vertikal dan foto condong. Foto udara vertikal dibuat dengan sumbu kamera yang arahnya setegak mungkin, dapat terjadi apabila 
sumbu kamera pada saat pemotretan benar-benar vertikal, sehingga bidang foto sejajar dengan bidangnya.

\subsection{Penggambaran dari suatu objek}

Penggambaran dari suatu objek disebut dengan Citra. terdapat dua jenis citra, citra analog dan citra digital. Komputer tidak dapat memproses citra analog secara langsung. Citra digital memilik jumlah data yang besar sehingga memerlukan daya komputasi tinggi. Terdapat dua parameter pada pixel, yaitu kordinat dan intensitasi. Penilai pada kordinat $(x, y)$ adalah $f(x, y)$ yaitu besar intensitas pixel pada titik tersebut. Maka citra digital ditulis bentuk matriks berikut :

$$
f(x, y)=\left[\begin{array}{cccc}
f(0,0) & f(0,1) & \ldots & f(0, M-1) \\
f(1,0) & \ldots & \ldots & f(1, M-1) \\
\ldots & \ldots & \ldots & \ldots \\
f(N-1,0) & f(N-1,1) & \ldots & f(N-1, M-1)
\end{array}\right]
$$

Dari gambar di atas, citra digital dapat dituliskan sebagai fungsi intensitas $f(x, y)$ dengan $x$ berupa (baris) dan $y$ berupa (kolom).

\subsection{Segmentasi Citra}

Segmentasi citra adalah proses pengolahan citra yang bertujuan untuk memisahkan antara objek (foreground) dengan latar belakang (background)

\subsection{Operasi Morfologi}

Operasi morfologi citra merupakan suatu proses yang bertujuan untuk bahan bentuk objek pada citra Asli.

\subsection{Rancangan Sistem}

Ada 2 perancangan sistem yang digunakan dimana pada rancangan pertama untuk mengklasifikasikan citra yang ada di lokasi penelitian

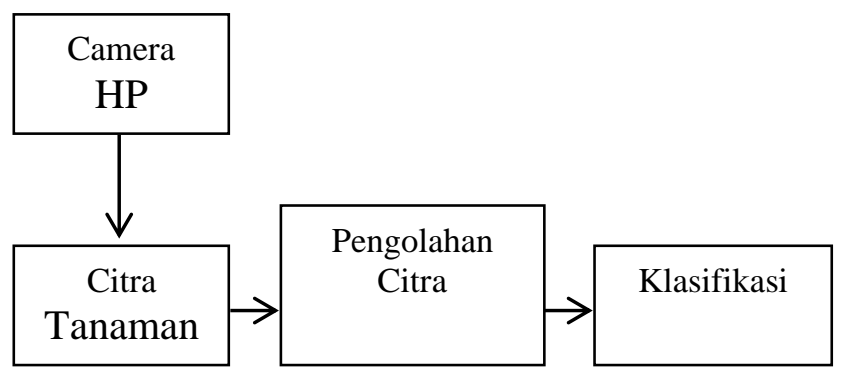

Gambar 2.1. Rancangan Pertama

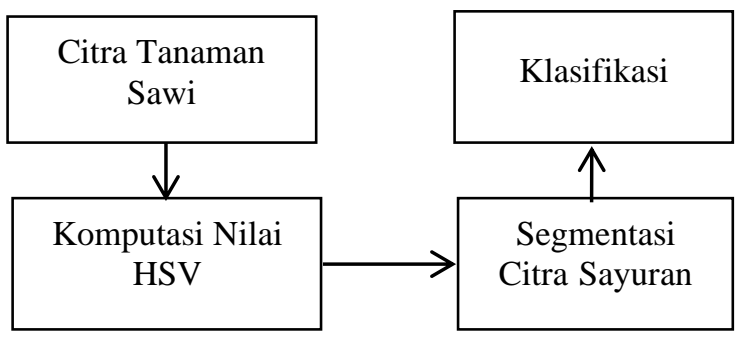


Gambar 2.2. Rancangan Kedua

\section{PEMBAHASAN}

\subsection{Pengambilan Citra Tanaman Sawi}

Pengambilan citra tanaman sawi di lakukan menggunakan HandPhone Vivo 1609 di lokasi tanaman sawi. Pada waktu pengambilan citra HandPhone Vivo 1609 menggunakan Tongsit dengan ketinggian 5 meter dari atas tanaman sawi yang sudah di tentukan terlebih dahulu posisi titik ketinggiannya, yaitu digunakan waktu antara 5 menit sampai 10 menit dalam satu kali mengambil citra. Proses pengambilan citra menggunakan HandPhone Vivo 1609 sebagai berikut :

1. Persiapan peralatan pengambilan citra tanaman sawi

2. Penentuan titik pengambilan gambar

3. HandPhone di pasang di Tongsit

4. Pengambilan citra melalui HandPhone dengan bantuan Tongsit setinggi 5 Meter

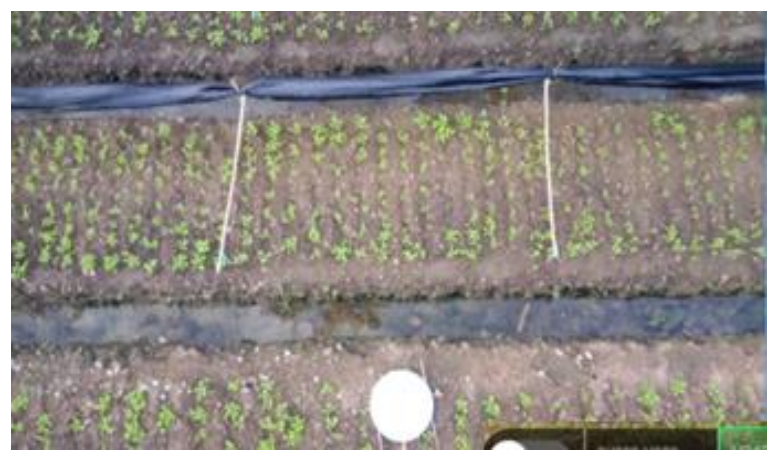

Gambar 3.1. Tampilan di layar HP pada saat pengambilan citra

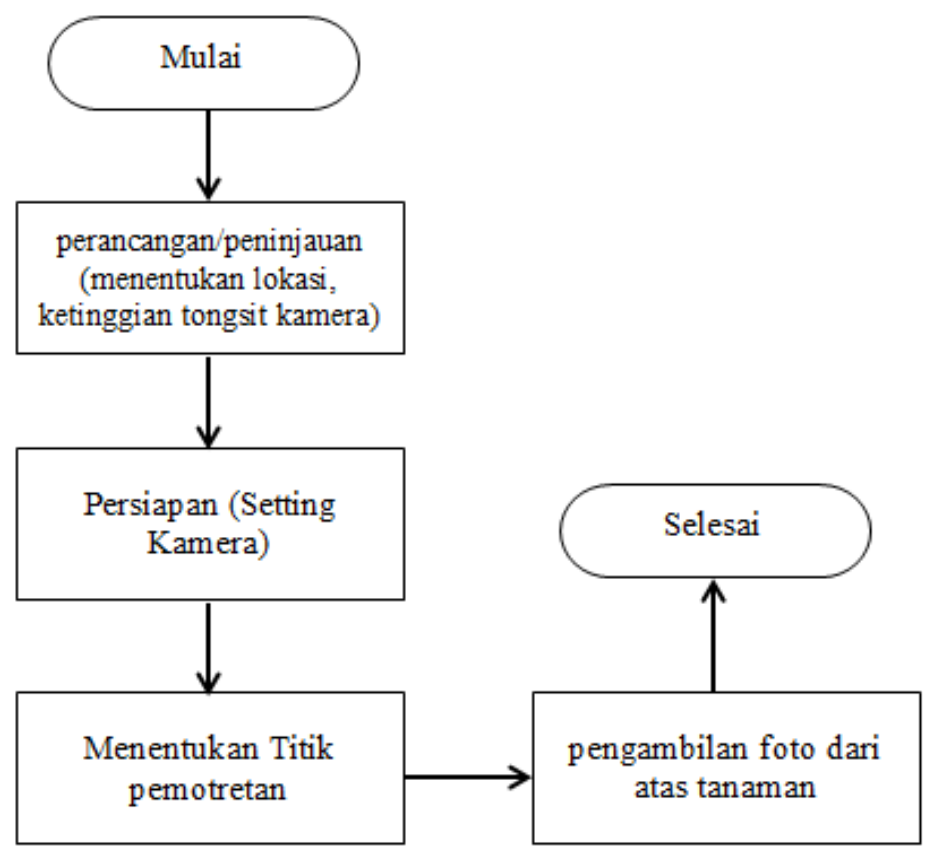


Gambar 3.2. Proses Pengambilan Citra HandPhone Vivo 1609

Tabel 1 Jumlah pengambilan citra Handphone Vivo 1609

\begin{tabular}{|c|c|c|c|c|c|c|c|c|}
\hline \multirow[t]{2}{*}{ Umur } & \multicolumn{3}{|c|}{ Warna } & \multicolumn{3}{|c|}{ Nilai } & \multirow{2}{*}{$\begin{array}{c}\text { Tinggi } \\
\text { Target }\end{array}$} & \multirow{2}{*}{$\begin{array}{c}\text { Jenis } \\
\text { Objek }\end{array}$} \\
\hline & $\mathrm{R}$ & $\mathrm{G}$ & B & $\mathrm{H}$ & $S$ & V & & \\
\hline 1 & 2 & 3 & 4 & 5 & 6 & 7 & 8 & 9 \\
\hline \multirow[t]{4}{*}{19 Hari } & 153 & 171 & 130 & $86.34^{0}$ & $23.98 \%$ & $67.06 \%$ & 5 Meter & Sayur \\
\hline & 99 & 133 & 65 & $90^{0}$ & $51.13 \%$ & $52.16 \%$ & 5 Meter & Sayur \\
\hline & 161 & 192 & 130 & $90^{\circ}$ & $32.29 \%$ & $75.29 \%$ & 5 Meter & Sayur \\
\hline & 134 & 169 & 78 & $83.08^{0}$ & $53.85 \%$ & $66.27 \%$ & 5 Meter & Sayur \\
\hline \multirow[t]{6}{*}{23 Hari } & 119 & 165 & 62 & $86.8^{0}$ & $62.42 \%$ & $64.71 \%$ & 5 Meter & Sayur \\
\hline & 138 & 171 & 78 & $81.29^{0}$ & $54.39 \%$ & $67.06 \%$ & 5 Meter & Sayur \\
\hline & 90 & 116 & 48 & $82.94^{0}$ & $58.62 \%$ & $45.49 \%$ & 5 Meter & Sayur \\
\hline & 156 & 194 & 95 & $83.03^{0}$ & $51.03 \%$ & $76.08 \%$ & 5 Meter & Sayur \\
\hline & 174 & 199 & 123 & $79.74^{0}$ & $38.19 \%$ & $78.04 \%$ & 5 Meter & Sayur \\
\hline & 110 & 150 & 77 & $92.88^{0}$ & $48.67 \%$ & $58.82 \%$ & 5 Meter & Sayur \\
\hline \multirow{4}{*}{26 Hari } & 221 & 239 & 146 & $71.61^{0}$ & $38.91 \%$ & $93.73 \%$ & 5 Meter & Sayur \\
\hline & 140 & 181 & 73 & $82.78^{0}$ & $59.67 \%$ & $70.98 \%$ & 5 Meter & Sayur \\
\hline & 196 & 231 & 121 & $79.09^{0}$ & $47.62 \%$ & $90.59 \%$ & 5 Meter & Sayur \\
\hline & 85 & 130 & 17 & $83.89^{0}$ & $86.92 \%$ & $50.98 \%$ & 5 Meter & Sayur \\
\hline \multirow[t]{8}{*}{30 Hari } & 116 & 143 & 68 & $81.6^{0}$ & $52.45 \%$ & $56.08 \%$ & 5 Meter & Sayur \\
\hline & 202 & 234 & 142 & $80.87^{0}$ & $39.32 \%$ & $91.76 \%$ & 5 Meter & Sayur \\
\hline & 224 & 253 & 151 & $77.06^{0}$ & $40.32 \%$ & $99.22 \%$ & 5 Meter & Sayur \\
\hline & 211 & 241 & 129 & $76.07^{0}$ & $46.47 \%$ & $94.51 \%$ & 5 Meter & Sayur \\
\hline & 46 & 102 & 7 & $95.37^{0}$ & $93.14 \%$ & $40 \%$ & 5 Meter & Sayur \\
\hline & 136 & 175 & 86 & $86.29^{0}$ & $50.86 \%$ & $68.63 \%$ & 5 Meter & Sayur \\
\hline & 99 & 157 & 56 & $94.46^{0}$ & $64.33 \%$ & $61.57 \%$ & 5 Meter & Sayur \\
\hline & 88 & 137 & 19 & $84.92^{0}$ & $86.13 \%$ & $53.73 \%$ & 5 Meter & Sayur \\
\hline \multirow[t]{4}{*}{33 Hari } & 105 & 162 & 38 & $87.58^{0}$ & $76.54 \%$ & $63.53 \%$ & 5 Meter & Sayur \\
\hline & 119 & 167 & 56 & $85.95^{0}$ & $66.47 \%$ & $65.49 \%$ & 5 Meter & Sayur \\
\hline & 15 & 54 & 7 & $109.79^{0}$ & $87.04 \%$ & $21.18 \%$ & 5 Meter & Sayur \\
\hline & 131 & 182 & 63 & $85.71^{0}$ & $65.38 \%$ & $71.37 \%$ & 5 Meter & Sayur \\
\hline
\end{tabular}

\subsection{Pengambilan Data Nilai HSV}

Untuk pengambilan nilai dilakukan dengan menggunakan imagecolorpicker.com yang dapat di akses melalui web browser secara on line, ada dua kelompok data yang dapat di identifikasi yaitu data warna RGB dan nilai HSV. Cara membuka imagecolorpicker.com, pastikan google.com sudah siap kemudian kita menginput atau mengetik di kolom browsernya imagecolorpicker.com selanjutnya pilih pencarian.

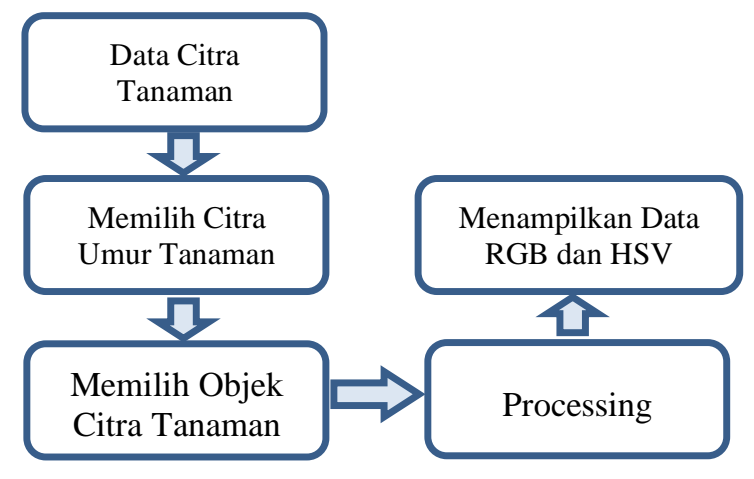


Gambar 3.4. Proses Pengambilan Data warna RGB dan nilai HSV pada Tanaman Sayur Sawi

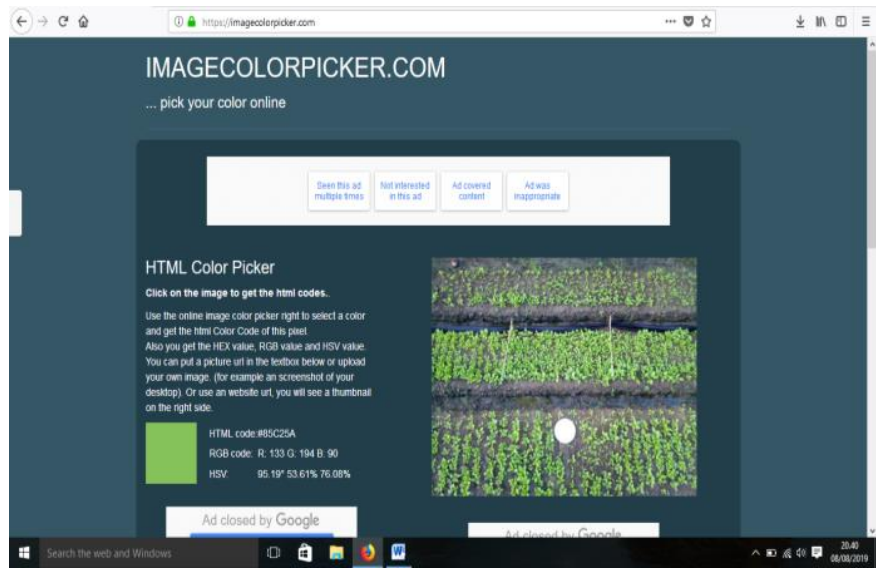

Gambar 3.5. Tampilan Aplikasi Imegecolorpicker.com

\begin{tabular}{|c|c|c|c|l|}
\hline No. & Umur & $\begin{array}{c}\text { Ketinggian } \\
\text { Tongsit }\end{array}$ & $\begin{array}{c}\text { Jumlah } \\
\text { Pengambilan }\end{array}$ & \multicolumn{1}{|c|}{ Keterangan } \\
\hline 1. & 18 Hari & 5 Meter & 7 kali & Berangin Kencang \\
\hline 2. & 22 Hari & 5 Meter & 5 kali & Berangin \\
\hline 3. & 26 Hari & 5 Meter & 8 kali & Berangin Kencang \\
\hline 4. & 30 Hari & 5 Meter & 2 kali & Tidak Berangin \\
\hline 5. & 34 Hari & 5 Meter & 4 kali & Berangin \\
\hline
\end{tabular}

Gambar 3.6. Tabel Pengambilan Foto Tanaman Sayur Sawi

Dari hasil rekapitulasi gambar tabel tersebut dapat disimpulkan sebagai berikut :

a. Warna green lebih besar nilai warnanya di banding warna red dan warna red nilai warnanya lebih besar di banding nilai warnanya blue berarti objeknya warna sayur.

b. Sekitar $82 \%$ warna red lebih besar nilai warnanya di banding warna blue sedangkan warna blue dengan warna green perbedaan jumlah nilai warnanya $50 \%$ berarti objeknya warna tanah.

c. Warna blue lebih besar nilai warnanya di banding warna green dan warna green lebih besar nilai warnanya di banding nilai warnanya red berarti objeknya warna terpal.

d. Sekitar $75 \%$ warna blue lebih besar nilai warnanya di banding warna green dan sekitar 99 $\%$ warna green lebih besar nilai warnanya red berarti objeknya warna air.

\subsection{Algoritma yang digunakan}


Proses perhitungan segmentasi nilai piksel sayur sawi tersebut menggunakan algoritma segmentasi warna dengan parameter hasil segmentasi nilai piksel RGB untuk mengetahui pertumbuhan tanaman sayur sawi, Algoritma yang digunakan untuk mencari hasil segmentasi nilai piksel RGB dan nilai HSVnya pada sayur sawi adalah :

$$
\begin{gathered}
\mathrm{H}=\mathrm{V}>\mathrm{S} \\
\mathrm{H}=\mathrm{HSV}, \mathrm{V}=\text { Value, } \mathrm{S}=\text { Saturation }
\end{gathered}
$$

\subsection{Proses Segmentasi Citra Tanaman Sayur Sawi}

Segmentasi citra adalah proses pengolahan citra yang bertujuan untuk memisahkan antara objek (foreground) dengan latar belakang (background).

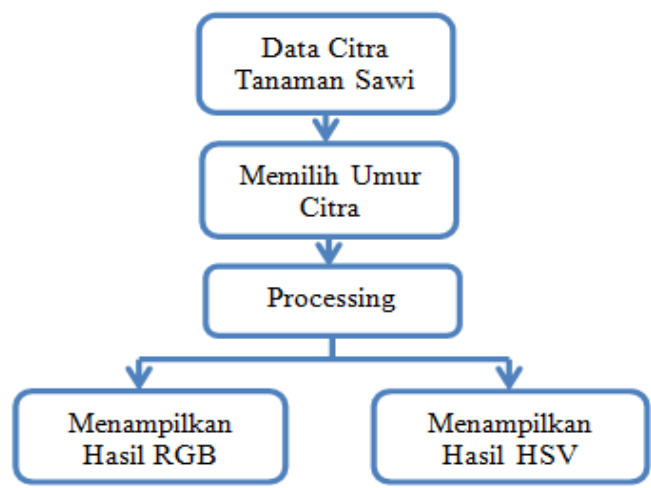

Gambar 3.7. Proses segmentasi nilai piksel warna RGB dan nilai HSV

\subsection{Simulasi Proses Segmentasi Nilai Piksel tanaman Sayur Sawi}

Simulasi proses segmentasi nilai piksel sayur sawi di mulai dari membuka aplikasi program Delphi 7 dan di jalankan dengan perintah tobol run, muncul sebagai berikut :

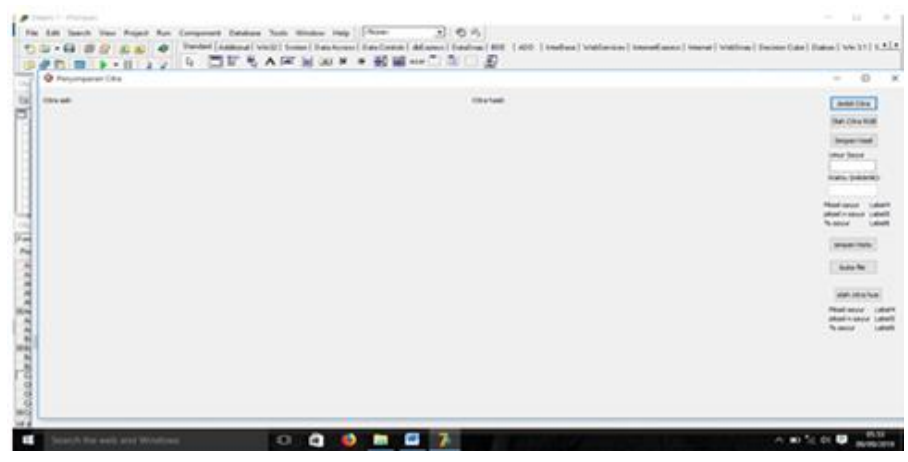

Gambar 3.8. Tampilan awal menggunakan program Delphi 7

Setelah tampilan awal muncul selanjutnya di pilih Ambil Citra untuk masuk melakukan pemilihan umur tanaman sawi yang sudah di simpan sebelumnya, kemudian tampil sebagai berikut : 


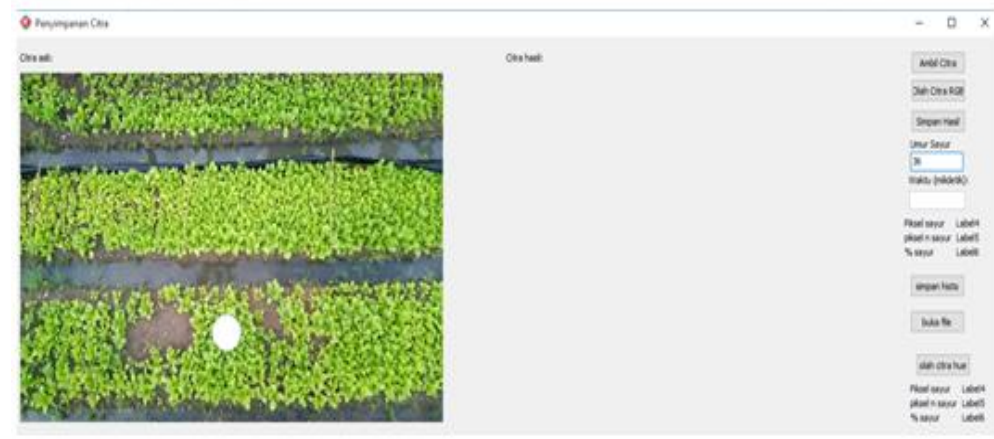

Gambar 3.9. Tampilan setelah mengambil citra Tanaman sawi

Setelah mengambil citra tanaman sawi tersebut, maka selanjutnya memilih menu Olah Citra $\boldsymbol{R} \boldsymbol{G B}$ untuk melakukan suatu proses perhitungan jumlah nilai piksel RGB dan nilai piksel HSV sayur sawi, kemudian tampil sebagai berikut :

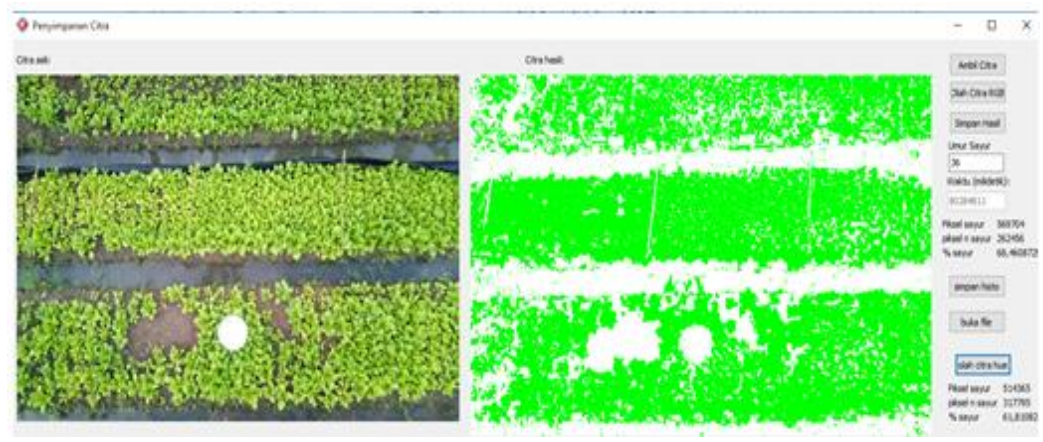

Gambar 3.10. Hasil proses segmentasi sayur sawi untuk menghasilkan nilai piksel HSV

\begin{tabular}{|c|c|c|c|}
\hline \multirow{2}{*}{ Umur sawi } & \multicolumn{3}{|c|}{ Nilai HS V } \\
\cline { 2 - 4 } & Piksel Sayur & Piksel N Sayur & $\begin{array}{c}(\%) \\
\text { Sayur }\end{array}$ \\
\hline 1 & 2 & 3 & 4 \\
\hline 18 Hari & 43263 & 72950 & 37,224 \\
\hline 22 Hari & 23662 & 56108 & 29,662 \\
\hline 26 Hari & 13447 & 63572 & 17,459 \\
\hline 30 Hari & 13160 & 70367 & 15,755 \\
\hline 34 Hari & 74483 & 92084 & 7,483 \\
\hline
\end{tabular}

Gambar 3.11. Gambar tabel Nilai HSV dari Hasil Segmentasi nilai piksel sayuran Menggunakan Program Delphi 7

Pada Tabel diatas menjelaskan bahwa dari hasil Segmentasi nilai Hue pada tanaman sayur sawi menggunakan Program Delphi 7, dengan mengelompokkan berdasarkan hasil segmentasi nilai Hue sayuran dalam persen dapat diuraikan bahwa umur tanaman sawi 18 hari 
nilai Hue yang terkandung pada sayur diatas dari 37 persen, umur tanaman sawi 22 hari nilai Hue yang terkandung pada sayur diatas dari 29 persen, umur tanaman sawi 26 hari nilai Hue yang terkandung pada sayuran diatas dari 17 persen, umur tanaman sawi 30 hari nilai Hue yang terkandung pada sayuran diatas dari 15 persen, umur tanaman sawi 34 hari nilai Hue yang terkandung pada sayuran diatas dari 7 persen, sedangkan umur tanaman sawi diatas dari 34 hari nilai Hue yang terkandung pada sayuran dibawah dari 7 persen dan sudah bisa di kelompokkan kedalam masa waktu panen tanaman sawi tersebut.

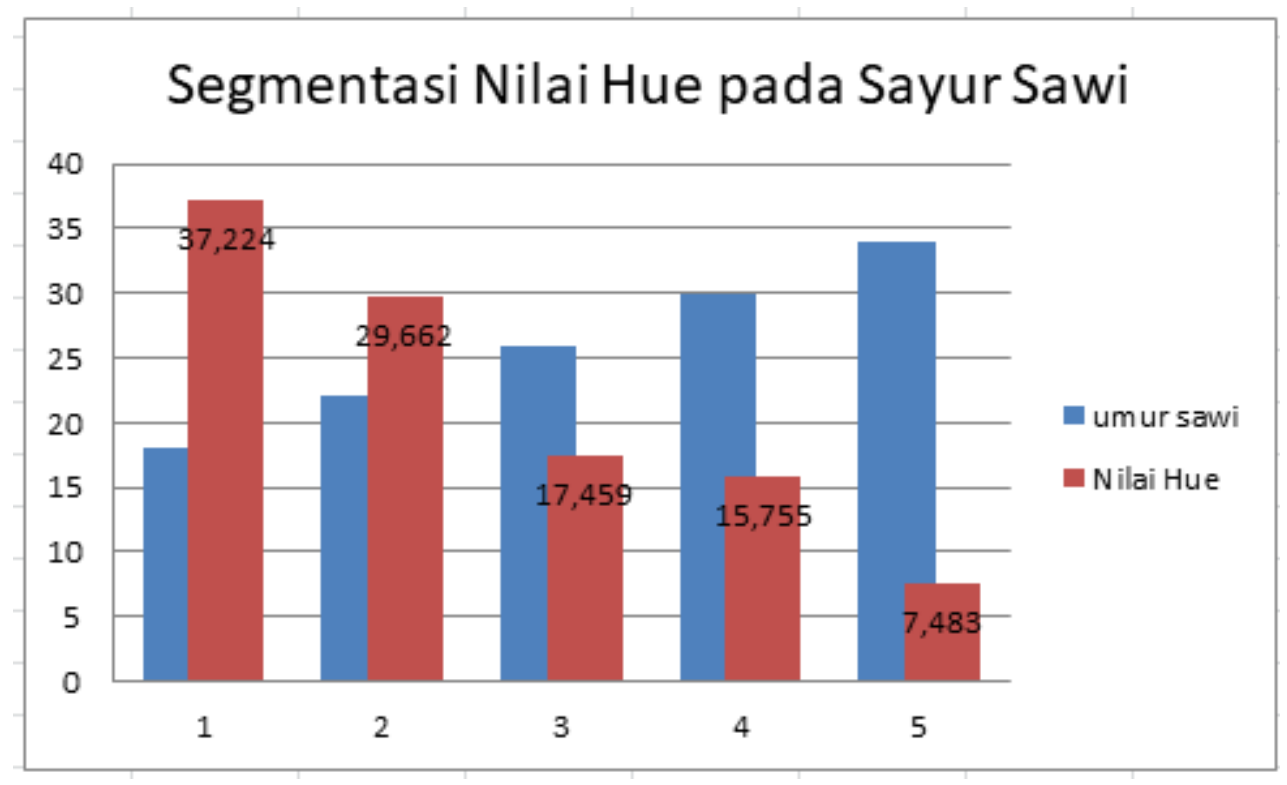

Gambar 3.12. Grafik Segmentasi Nilai Hue pada Tanaman Sayur Sawi

Dari gambar 4.5. menjelas bahwa nilai hue pada tanaman sayur sawi sangat mempengaruhi perkembangan pertumbuhannya dimana semakin lama umur tanaman sayur sawi semakin kecil nilai Hue yang terkandung pada tanaman sayur sawi tersebut dan ini menandakan bahwa tanaman sayur sawi tersebut mengalami perkembangan pertumbuhan yang sangat baik dengan kata lain tanaman sayur sawi tumbuh dengan baik dan menghasilkan hasil yang banyak.

\section{KESIMPULAN}

Dari penelitian yang telah dilakukan, dapat mengambil kesimpulan sebagai berikut :

1. Pada umur tertentu tanaman sayur sawi menghasilkan nilai Hue yang berbeda, dimana tanaman sayur sawi yang berumur 18 hari sampai 22 hari menghasilkan nilai Hue antara $37,224 \%$ sampai $29,662 \%$, sayur sawi yang berumur 22 hari sampai 26 hari menghasilkan nilai Hue antara 29,662\% sampai 17,459\%, sayur sawi yang berumur 26 hari sampai 30 hari menghasilkan nilai Hue 17,459 \% sampai 15,755 \%, sayur sawi yang 
berumur 30 hari sampai 34 hari menghasilkan nilai Hue 15,755 \% samapi 7,483\% . Jika tanaman sayur sawi tersebut nilai Huenya kurang dari nilai standar maka tanaman tersebut bisa di prediksi ada gangguan atau tanamannya kurang baik pertumbuhannya, begitu juga kalau tanaman sayur sawinya melebihi dari nilai Hue standar tersebut bisa diprediksi pertumbuhan tanaman sayur sawinya dalam keadaan normal atau baik.

2. Di dalam penelitian telah dilakukan pengambilan citra tanaman sayur sawi dengan menggunakan kamera handphone vivo 1609 dengan alat bantu menggunakan tongsit setinggi 5 (lima) meter diatas permukaan tanaman sayur sawi, apabila ketinggian tongsit kurang dari 5 (lima) meter, maka kamera handphone tidak menjangkau seluruh permukaan tanaman sayur sawi dan apabila ketinggian tongsit lebih dari 5 (lima) meter maka jangkauannya melebihi permukaan tanaman sayur sawi dari titik yang telah ditentukan.

3. Hasil dari proses aplikasi pengolahan citra, petani dapat memperoleh sebuah informasi nilai Hue yang terkandung di sayur sawi pada umur tertentu.

\section{REFERENSI}

[1] Kamelia Munthe, Erwin Pane, dan Ellen L. Panggabean. 2018. Budidaya Tanaman Sawi (Brassica juncea) Pada Media Tanam Yang Berbeda Secara Vertikultur. Universitas Medan Area, Medan.

[2] Rahmat Rukmana. 2020. Bertanam Petsai dan Sawi. Kanisius, Yogyakarta.

[3] Fajar Astuti Hermawati, 2018. "Teori Pengolahan Citra Digital : Konsep dan Teori ", Andi, Yogyakarta.

[4] Margi Cahyanti, Ravi A. Salim, Moch. Wisuda, 2016. Implementasi pengolahan citra untuk pengenalan citra bendera negara berdasarkan warna. Universitas Gunadarma,

[5] Purnomo Mauridhi Hery, Muntasa Arif, 2010. "Konsep Pengolahan Citra Digital dan Ektraksi Fitur “, Graha Ilmu Yogyakarta.

[6] Erawan. D, Y. Wa Ode dan Bahrun. 2013. Pertumbuhan dan Hasil Tanaman Sawi (Brassica juncea, L.) pada Berbagai Dosis Pupuk Urea, Jurnal Agroteknos, 3 (1) : 19-25.

[7] Wahyudi. 2010. Petunjuk Praktis Bertanam Sayuran. Agromedia Pustaka. Jakarta

[8] Ramadhani., Yoniar Hufan., et Al., (2015) Pemetaan Pulau Kecil dengan Pendekatan Berbasis Objek menggunakan Data Unmanned Aerial Vehicle (UAV)., Jurnal Majalah Ilmiah Globe, Volume 17 No.2 Desember 2015:125-134 